\title{
Low Temperature Decomposition Rates for Tetraphenylborate Ion
}

by

D. D. Walker

Westinghouse Savannah River Company

Savannah River Site

Aiken, South Carolina 29808

This paper was prepared in connection with work done under the above contract number with the U.S. Department of Energy. By acceptance of this paper, the publisher and/or recipient acknowledges the U.S. Government's right to retain a nonexclusive, royalty-free license in and to any copyright covering this paper, along with the right to reproduce and to authorize others to reproduce all or part of the copyrighted paper. 


\section{DISCLAIMER}

This report was prepared as an account of work sponsored by an agency of the United States Government. Neither the United States Government nor any agency thereof, nor any of their employees, makes any warranty, express or implied, or assumes any legal liability or responsibility for the accuracy, completeness, or usefulness of any information, apparatus, product, or process disclosed, or represents that its use would not infringe privately owned rights. Reference herein to any specific commercial product, process, or service by trade name, trademark, manufacturer, or otherwise does not necessarily constitute or imply its endorsement, recommendation, or favoring by the United States Government or any agency thereof. The views and opinions of authors expressed herein do not necessarily state or reflect those of the United States Government or any agency thereof.

This report has been reproduced directly from the best available copy.

Available to DOE and DOE contractors from the Office of Scientific and Technical Information, P.O. Box 62, Oak Ridge, TN 37831; prices available from (615) 576-8401.

Available to the public from the National Technical Information Service, U.S. Department of Commerce, 5285 Port Royal Road, Springfield, VA 22161. 


\section{DISCLAIMER}

Portions of this document may be illegible in electronic image products. Images are produced from the best available original document. 
WSRC-TR-98-00342, Rev. 0

Keywords: In-Tank Process, Benzene

Retention: Permanent

\section{LOW TEMPERATURE DECOMPOSITION RATES FOR TETRAPHENYLBORATE ION}

D. D. Walker

Publication Date: October 2, 1998

Westinghouse Savannah River Company Savannah River Technology Center A iken, SC 29808

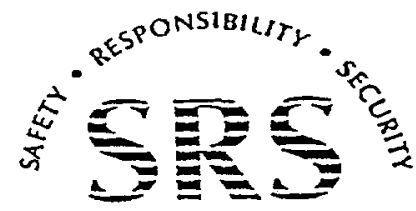

SAVANNAH RIVER SITE 
WSRC-TR-98-00342 Rev.0

Page 2 of 21

Low Temperature Decomposition Rates for Tetraphenylborate Ion

Author

$\frac{\text { Gavel A. Colleen }}{\text { D. D. Walker, Waste Processing Technology }}$

Design Check

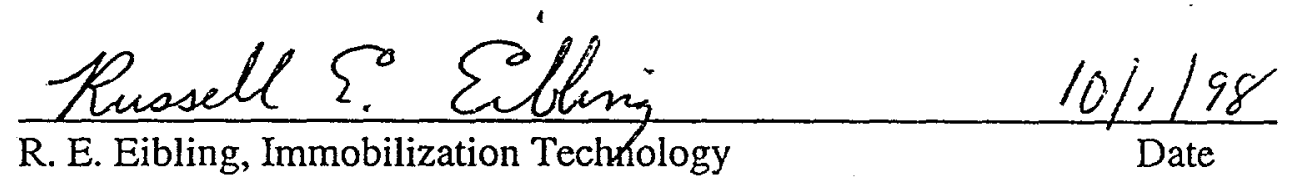
(per Manual E7, Procedure 2.40)

Approvals

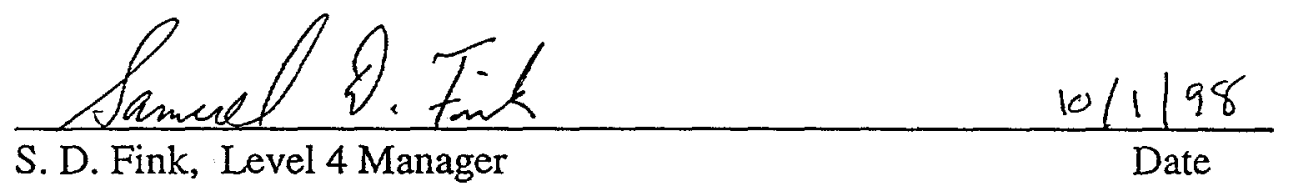
Waste Processing Technology

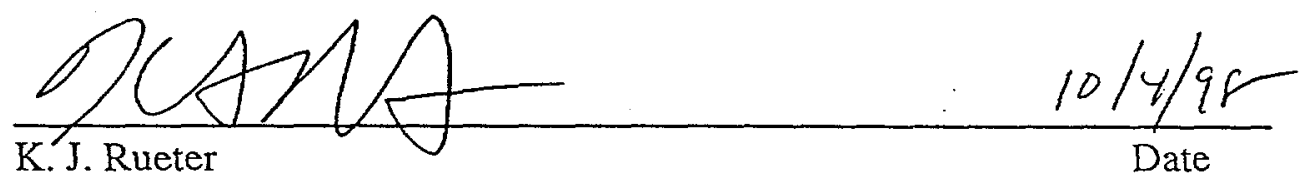

Salt Disposition Systems Engineering Team

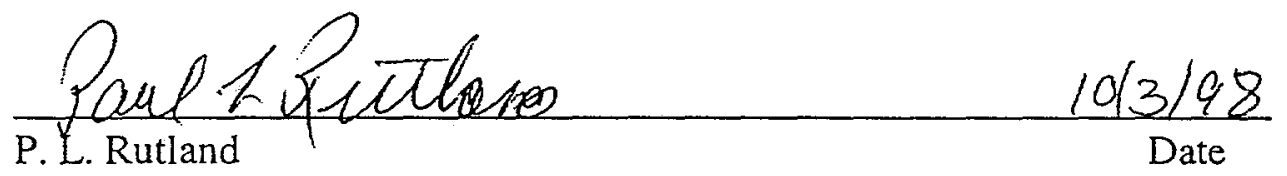

In-Tank Precipitation Flowsheet Team

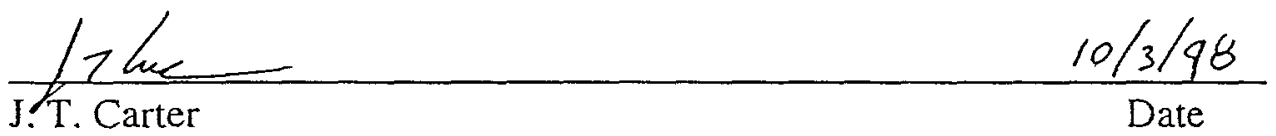

In-Tank Precipitation Flow Sheet Team Leader

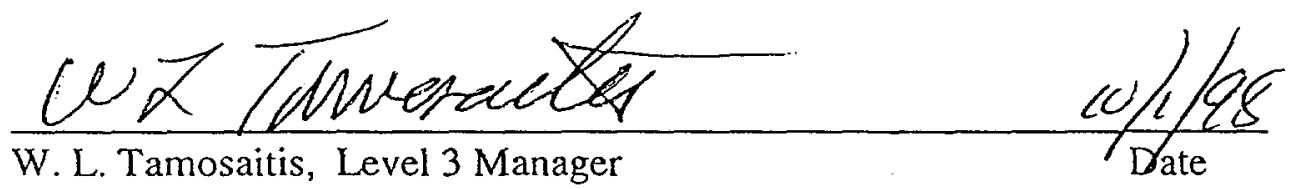

Waste Processing Technology 


\section{CONTENTS}

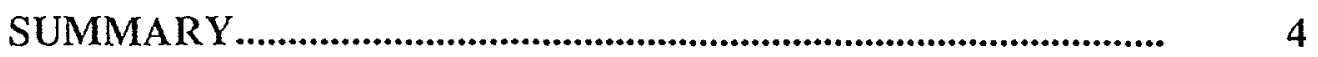

INTRODUCTION...................................................................... 4

TEST DESIGN AND RESULTS.......................................... 5

TPB $^{-}$Reaction Rates with Activated Catalyst................. 5

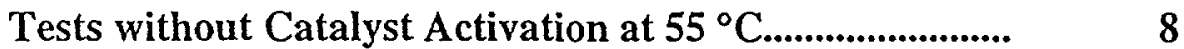

Effect of Palladium Concentration................................... . 9

Effect of Oxygen..................................................... 9

Effect of Platinum......................................... 11

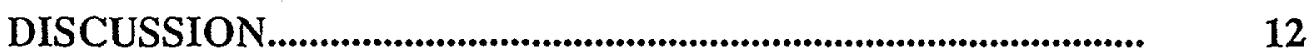

UNCERTAINTIES IN CURRENT WORK .......................... 12

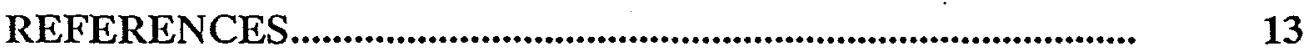

APPENDIX A: Experimental............................................. 15 


\title{
LOW TEMPERATURE DECOMPOSITION RATES FOR TETRAPHENYLBORATE ION
}

\author{
By D. D. WALKER
}

\section{SUMMARY}

Palladium catalyzes the decomposition of tetraphenylborate in alkaline solutions. Researchers postulate that the decomposition mechanism includes a catalyst activation step and a tetraphenylborate (TPB) decomposition step. Experiments reported below separated the two steps and clarified the mechanism of the reaction. These tests show the following.

- Tetraphenylborate reacts at a measurable rate at $25^{\circ} \mathrm{C}$ in the presence of active catalyst.

- The activation energy for the reaction is $46.8( \pm 3.4) \mathrm{kJ} / \mathrm{mole}$.

- No "temperature cliff" exists between $35^{\circ} \mathrm{C}$ and $25^{\circ} \mathrm{C}$ below which TPB- does not decompose.

- Catalyst activation is very sensitive to oxygen.

- Oxygen prevents catalyst activation at $25^{\circ} \mathrm{C}$ in laboratory-scale tests.

- In the absence of oxygen, the catalyst activation step causes a delay in the onset of $\mathrm{TPB}^{-}$decomposition. The length of the delay depends on temperature, lasting less than a day at $55^{\circ} \mathrm{C}$ and over a week at $25^{\circ} \mathrm{C}$ for laboratory-scale tests.

- In the absence of oxygen, the catalyst activation step depends on the initial concentration of $\mathrm{Pd}(\mathrm{M})$.

- The rate of decomposition of $\mathrm{TPB}^{-}$at $45^{\circ} \mathrm{C}$ varied only $30 \%$ when the initial Pd (II) concentration varied over the range 0.65 to $5.2 \mathrm{mg} \mathrm{Pd} / \mathrm{L}$.

- No reaction occurred at $45^{\circ} \mathrm{C}$ when platinum(IV) replaced palladium(II).

- The platinum(IV) did not convert to an insoluble form as does palladium when activated.

\section{INTRODUCTION}

Previous studies indicated that palladium is catalyzes rapid decomposition of alkaline tetraphenylborate slurries. ${ }^{1-5}$ Additional evidence suggests that $\mathrm{Pd}(\mathrm{II})$ reduces to $\mathrm{Pd}(0)$ during catalyst activation. ${ }^{6}$ Further use of tetraphenylborate ion in the decontamination of radioactive waste may require removal of the catalyst or cooling to temperatures at which the decomposition reaction proceeds slowly and does not adversely affect processing. 
Recent tests ${ }^{7}$ showed that tetraphenylborate did not react appreciably at $25^{\circ} \mathrm{C}$ over six months suggesting the potential to avoid the decomposition at low temperatures. The lack of reaction at low temperature could reflect very slow kinetics at the lower temperature, or may indicate a catalyst "deactivation" process. Previous tests in the temperature range 35 to $70^{\circ} \mathrm{C}$ provided a low precision estimate of the activation energy of the reaction with which to predict the rate of reaction at $25^{\circ} \mathrm{C}$. To understand the observations at $25^{\circ} \mathrm{C}$, experiments must separate the catalyst activation step and the subsequent reaction with TPB. Tests described in this report represent an initial attempt to separate the two steps and determine the rate and activation energy of the reaction between active catalyst and TPB'. The results of these tests indicate that the absence of reaction at $25^{\circ} \mathrm{C}$ was caused by failure to activate the catalyst or the presence of a deactivating mechanism. In the presence of activated catalyst, the decomposition reaction rate is significant.

This work fulfills a request from P. L. Rutland, "TPB Solids Stability," Technical Task Request \#HLE-TAR-98059, Rev.0, March 11, 1998. The work complies with the following plan: D. D. Walker, "Scoping Tests for Low Temperature Tetraphenylborate Decomposition," SRT-LWP-98-0019, Rev.0, June 5, 1998. The testing supports design of the Small Tank Precipitation process. ${ }^{8}$

\section{TEST DESIGN AND RESULTS}

Researchers initially investigated the rate of reaction of TPB' following catalyst activation at temperatures in the range 25 to $55^{\circ} \mathrm{C}$, the rate of reaction of TPB without catalyst activation over the same temperature range, and the effect of initial $\mathrm{Pd}$ concentration on the rate of TPB decomposition at $45^{\circ} \mathrm{C}$. After the reaction of TPB at $25^{\circ} \mathrm{C}$ occurred, a comparison of the previous tests by $\mathrm{Barnes}^{7}$ and the current tests revealed several potentially significant differences. Additional tests examined several of these differences.

All of the tests slurries contained 5 wt \% KTPB solids in a 2.8 molar $\mathrm{Na}^{+}$salt solution. with an anion distribution reflecting the average SRS soluble waste composition (Table A-1, Appendix A). The slurries were carefully prepared to contain soluble TPB(approximately 0.015 molar) but no sodium tetraphenylborate (NaTPB) solids. The presence of solids would provide an additional source of TPB ${ }^{-}$and result in concentration changes that do not follow simple reaction kinetics. The low sodium concentration ensured sufficient soluble TPB $^{-}$initially present to allow catalyst activation and subsequent monitoring of the decomposition reaction. The tests used catalyst components added at the same concentrations as previous tests ${ }^{i-5}$ (called the Extended Comprehensive Catalyst, or 1X ECC). Table A-2, Appendix A, lists the catalyst components and concentrations.

\section{TPB $^{-}$Reaction Rates with Activated Catalyst}

These tests activated catalyst by heating at $55^{\circ} \mathrm{C}$ for approximately 19 hours. Within this . time, approximately half of the initial soluble tetraphenylborate decomposed. The 
slurries then cooled to the desired temperature $\left(25,30,35\right.$, or $\left.45^{\circ} \mathrm{C}\right)$. Subsequent sampling and analysis provided data for calculation of the reaction rates at the lower temperatures. In all cases, the reaction rates showed first order dependence on the TPBconcentration.

$$
\begin{aligned}
& \text { Reaction rate }(\text { molar } / \mathrm{hr})=\mathrm{k}\left[\mathrm{TPB}^{-}\right] \\
& \text {where } \mathrm{k}=\text { rate constant }\left(\mathrm{h}^{-1}\right) \\
& \text { and }\left[\mathrm{TPB}^{-}\right]=\text {concentration of } \mathrm{TPB}^{-} \text {(molar) }
\end{aligned}
$$

The rate constants equal the slope of a plot of time versus the logarithm of the TPB concentration. Figure 1 shows the change in TPB' concentration with time. Appendix contains tables of the concentration data. Table I, below, lists the rate constants for loss of $\mathrm{TPB}^{-}$ion. Figure 2 shows an Arrhenius plot of the rate constants. The data is linear and the triplicate data points at $25^{\circ} \mathrm{C}$ do not suggest any unusual temperature dependence in the 25 to $35^{\circ} \mathrm{C}$ range. The slope of the line yields the activation energy of the reaction based on the following equation.

$$
\ln \mathrm{k}=-\mathrm{E}_{\mathrm{a}} / \mathrm{RT}
$$

where $E_{\mathrm{a}}$ is the Arrhenius activation energy ( $\mathrm{kJ} / \mathrm{mole}$ )

$R$ is the gas constant $\left(8.314 \mathrm{~J} /{ }^{\circ} \mathrm{K} /\right.$ mole $)$

and $\mathrm{T}$ is temperature $\left({ }^{\circ} \mathrm{K}\right)$.

The activation energy is $46.8( \pm 3.4) \mathrm{kJ} /$ mole. The magnitude of the activation energy indicates the reaction rate will double for every $10^{\circ} \mathrm{C}$ increase in temperature in the range 25 to $55^{\circ} \mathrm{C}$. This result is within the range of previously reported values, but with a much smaller uncertainty. Crawford ${ }^{9}$ and Peterson ${ }^{10}$ previously estimated the activation energy, respectively, as $43 \pm 20$ and $39 \pm 20 \mathrm{~kJ} / \mathrm{mole}$.

Table I. Rate Constants (k) for Reaction of TPB` with Activated Catalyst*

$\begin{array}{cl}\text { Temperature }\left({ }^{\circ} \mathrm{C}\right) & \frac{\mathrm{k}\left(\mathrm{h}^{-1}\right)}{0.00452} \pm .00017 \\ 30 & -.00511 \\ 35 & -.00709 \\ 45 & -.0124 \\ 55 & -.0273\end{array}$

* Catalyst activated by heating the slurry to $55^{\circ} \mathrm{C}$ for 19 hours. Calculations of rate constants use only data collected after 19 hours. 


\section{FIGURE 1. Changes in Tetraphenylborate Concentration}

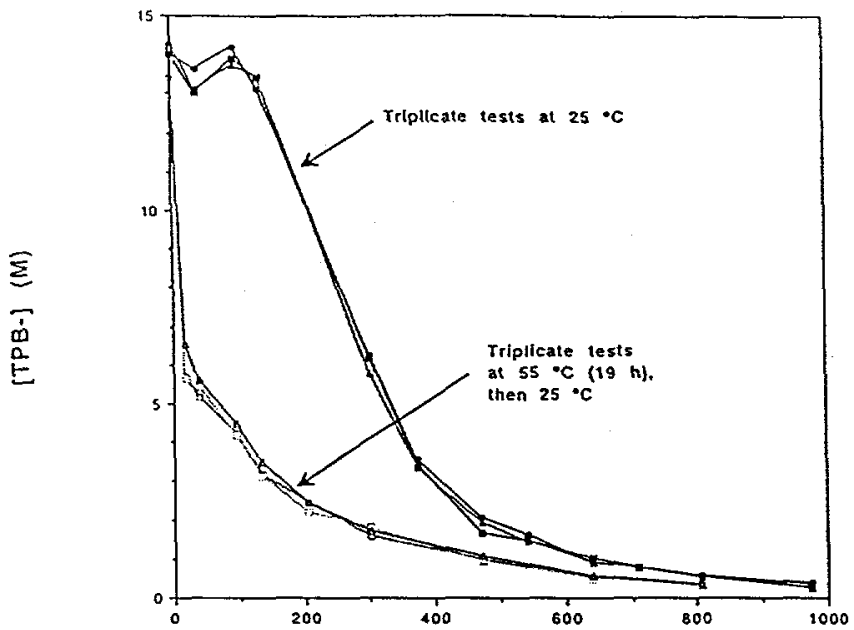

Time (h)

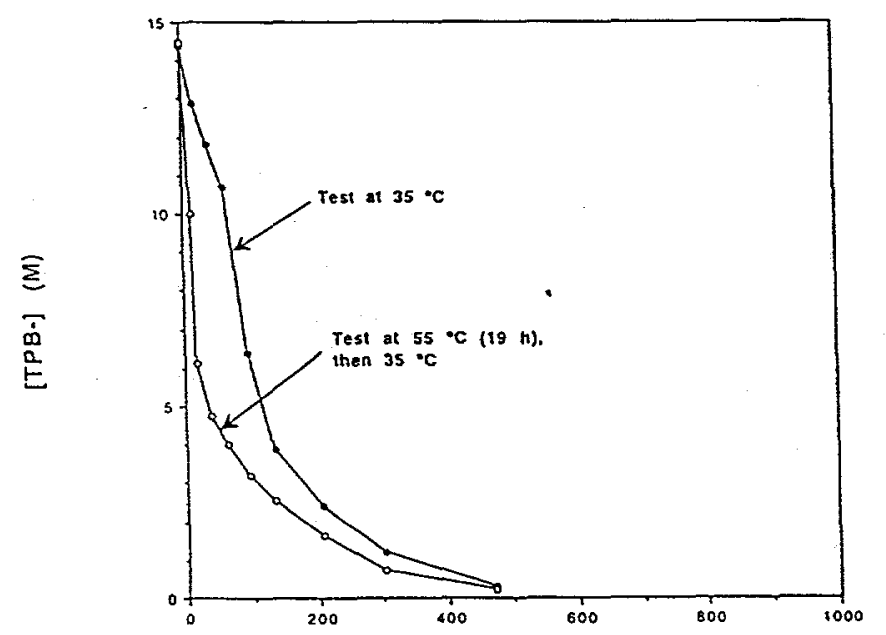

Time (h)
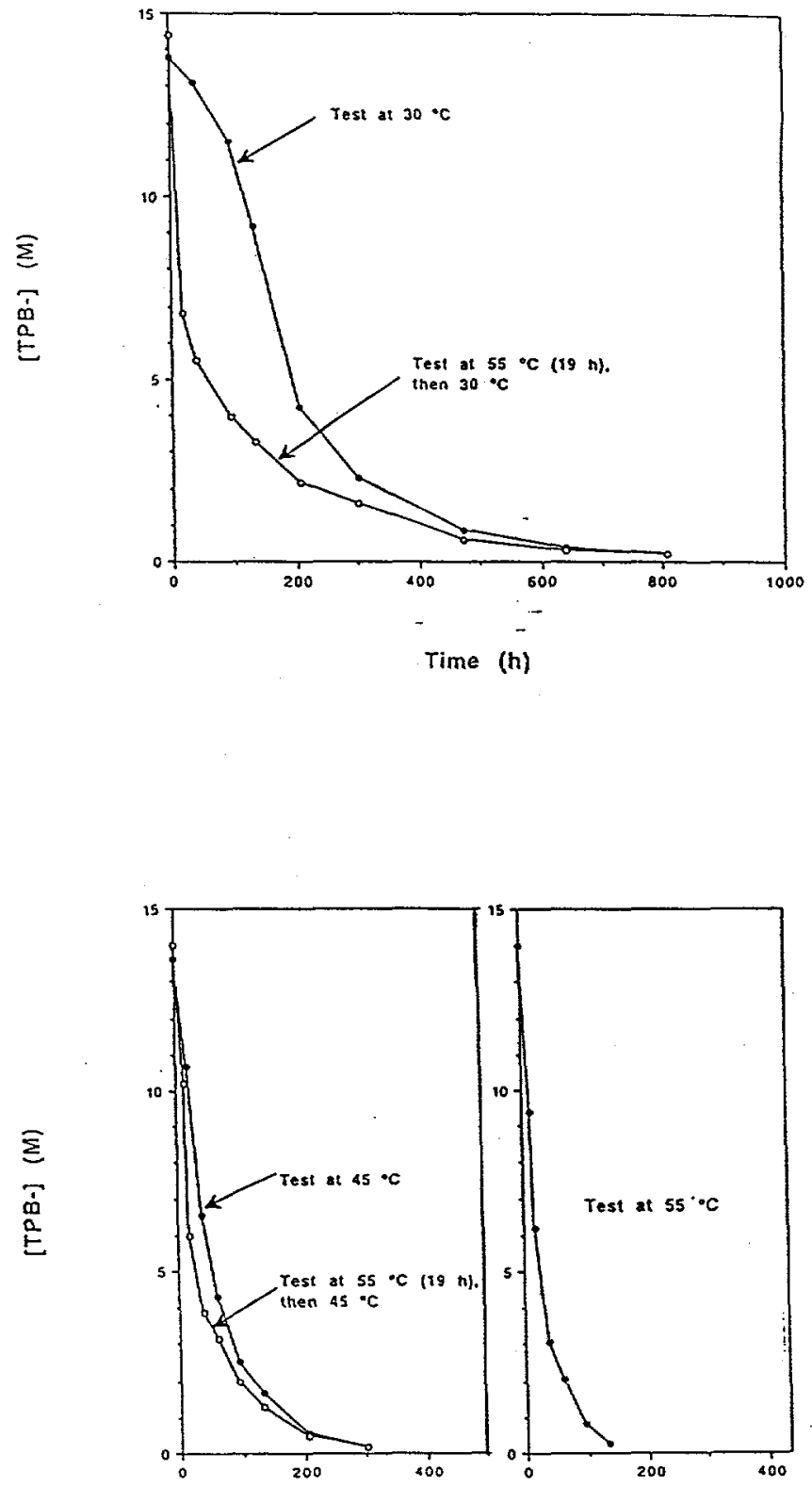

Time (h) 
Figure 2. Temperature Dependence of the Rate of Reaction of TPB with Activated Catalyst.

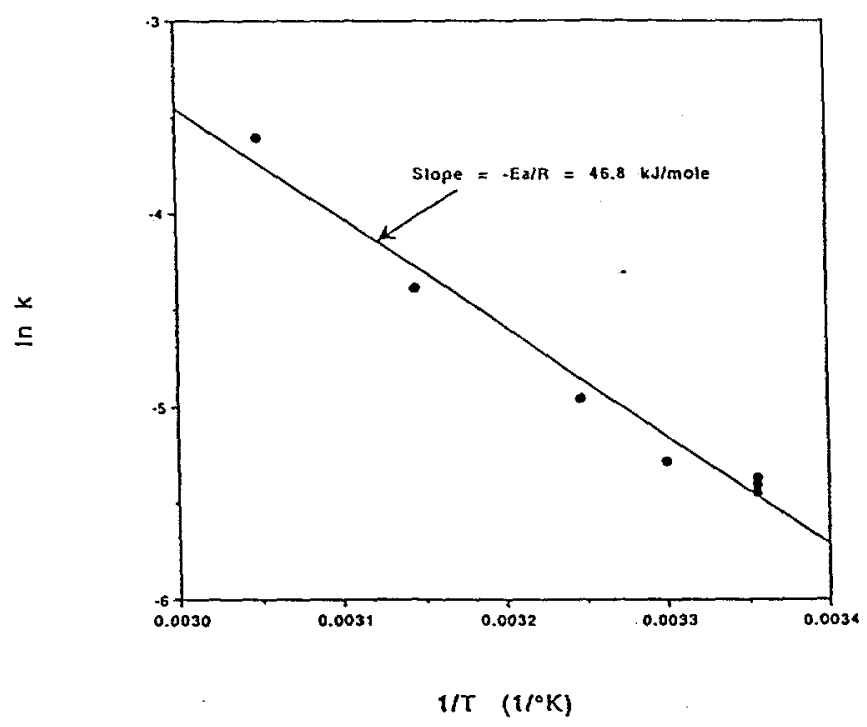

\section{Tests without Catalyst Activation at $55^{\circ} \mathrm{C}$}

A second set of tests placed the slurries in water baths at the lower temperatures at the start of the test. Table II lists the rate constants from these experiments. Figure 1 shows the changes in $\mathrm{TPB}^{-}$concentration for these tests. At each temperature, the reaction was slow initially but eventually showed first order dependence on the concentration of TPB: The time required to reach the maximum rate decreased as the temperature increased. The author calculated the rate constants for the first order reaction from data after the inflection point in each graph. The rate constants averaged $12 \%$ higher than in the corresponding test with the catalyst activated by heating to $55^{\circ} \mathrm{C}$ for 19 hours. The difference could reflect more complete activation over the longer time periods in spite of the lower temperatures.

TABLE II. Rate Constants (k) for Reaction of TPB- without Preactivation of Catalyst

Temperature $\left({ }^{\circ} \mathrm{C}\right)$

25

30

35

45 $\underline{\mathrm{k}\left(\mathrm{h}^{-1}\right)^{*}}$

$-.00476 \pm .00004$

$-.00529$

$-.00874$

$-.0145$

*Rate constants were calculated from data following the inflection point in the graph of $\left[\mathrm{TPB}^{-}\right]$vs. time (see Figure 1). 
TABLE III. Effect of Temperature and Palladium Concentration on Delay Times

\begin{tabular}{lc} 
Temperature $\left({ }^{\circ} \mathrm{C}\right)$ & Delay time $(\mathrm{h})$ \\
\hline 25 & 200 \\
$25,5 \mathrm{X} \mathrm{Pd}^{*}$ & $<24$ \\
30 & 100 \\
35 & 70 \\
45 & 20
\end{tabular}

*Pd concentration ( $13 \mathrm{mg} / \mathrm{L})$ five times greater than the nominal ECC concentration $(2.6 \mathrm{mg} / \mathrm{L})$ used in other tests.

The length of the delay in the onset of the rapid reaction varied with temperature and $\mathrm{Pd}$ concentration. Table III lists approximate delay times estimated from the inflection point in the graphs. At all temperatures above $25^{\circ} \mathrm{C}$, measurable loss of TPB $(\sim 25 \%)$ occurred during the delay period. At $25^{\circ} \mathrm{C}$, loss of $\mathrm{TPB}^{-}$was not significant for the 200 hours prior to onset of the reaction.

\section{Effect of Palladium Concentration}

Testing measured the effect of the initial palladium concentration at 25 and $45^{\circ} \mathrm{C}$. Figure 3 shows the changes in [TPB'] for each test and Table IV lists the rate constants. The $\mathrm{Pd}$ dependence observed in these tests appears contradictory. At $25^{\circ} \mathrm{C}$, the rate constant varies approximately proportional to the initial $\mathrm{Pd}$ concentration. However, at $45^{\circ} \mathrm{C}$, the rate constant appears relatively independent of the initial palladium concentration, varying by only $50 \%$ as the Pd changed by $800 \%$. The results suggest either of two possible explanations. The reaction mechanism may shift between 25 and $45^{\circ} \mathrm{C}$ such that $\mathrm{Pd}$ participates in the rate-determining step at the lower, but not at the higher, temperature. Alternatively, the catalyst activation reaction at $25^{\circ} \mathrm{C}$ may depend on the amount of $\mathrm{Pd}$ while the yield at higher temperature does not. Either explanation seems to suggest a much more complex reaction system than seems probable. Hence, the dependency of reaction rate on palladium requires additional investigation.

\section{Effect of Oxygen}

The decomposition within two weeks at $25^{\circ} \mathrm{C}$ in the tests without catalyst activation by treatment at $55^{\circ} \mathrm{C}$ contrasts with previous work in which negligible reaction occurred for over six months. Comparison of the two test protocols identified the following differences.

1. Although both test sets used the same palladium stock solution, unidentified solids precipitated between the two studies. The solids might contain $\operatorname{Pd}(0)$, the presumed form of the activated catalyst. Use of this solution could have provided Pd in the correct oxidation, thus circumventing the activation step. The soluble palladium concentration did not change significantly due to the precipitation of solids. 
FIGURE 3. Effect of Initial Palladium Concentration on Decomposition of TPB-

$25^{\circ} \mathrm{C}$

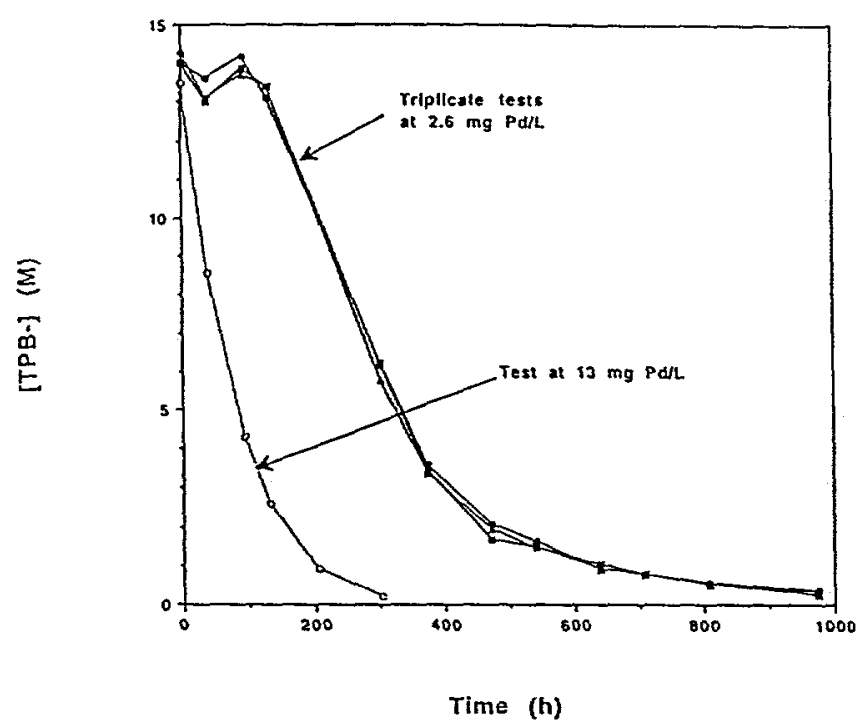

$45^{\circ} \mathrm{C}$

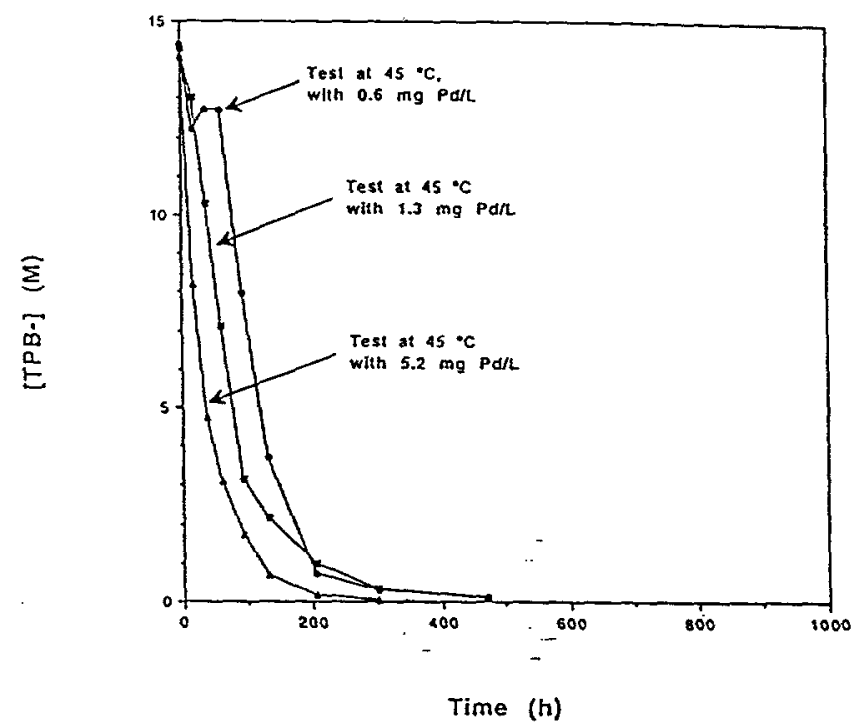

TABLE IV. Effect of Initial Palladium Concentration on Rate Constants (k)*

\begin{tabular}{|c|c|c|}
\hline Temperature $\left({ }^{\circ} \mathrm{C}\right)$ & Initial Pd $(\mathrm{mg} / \mathrm{L})$ & $\underline{\mathrm{k}\left(\mathrm{h}^{-1}\right)}$ \\
\hline \multirow[t]{2}{*}{25} & 2.6 & -0.00452 \\
\hline & 13. & -0.0141 \\
\hline \multirow[t]{4}{*}{45} & 0.65 & -0.0162 \\
\hline & 1.3 & -0.0125 \\
\hline & 2.6 & -0.0145 \\
\hline & 5.2 & -0.0184 \\
\hline
\end{tabular}

* From isothermal tests without catalyst activation at $55^{\circ} \mathrm{C}$. 
2. The tests by Barnes used significantly higher concentrations of the intermediate compounds triphenylborane (3PB), diphenylborinic acid (2PB), and phenylboronic acid (1PB). Previous studies suggest that higher concentrations of the intermediates can prevent reaction of TPB-

3. The tests by Barnes used a covered water bath, thus excluding light except during sampling. The current tests used clear serum vials under laboratory fluorescent lighting. Light might initiate reaction.

4. The tests by Barnes were initially purged, but subsequent sampling likely allowed air to leak into the serum vials. The current tests excluded air by pressurizing the vials with nitrogen during sampling. Previous studies showed that oxygen affects the reaction. In particular, oxygen can prevent reduction of $\mathrm{Pd}(\mathrm{II})$ to $\mathrm{Pd}(0)$, the likely form of the active catalyst.

Additional tests examined if any of the differences contributed to the observed reactivity difference between the two test sets. Table V lists the test conditions and results. The results indicate the presence of oxygen as the likely reason for the lack of reaction in the Barnes tests. However, the presence of high intermediates also affects the reaction. The high intermediate concentrations appear to reduce the reactivity but the effect seems too small to cause the difference observed in the two test sets. Barnes' tests could detect a $23 \%$ drop in $\mathrm{TPB}^{-}$and corresponding increase in $3 \mathrm{~PB}$ and $2 \mathrm{~PB}$ such as seen in the "high intermediates" test in Table V.

\section{TABLE V. Test Conditions and Results *}

\section{Test Condition}

Control*

Pd solids in stock solution removed by 0.2 micron filter

High intermediates (increased by $400 \%$ to match Barnes' concentrations)

Light eliminated by painting vial black

Air injected at each sampling time

Combined ( used filtered stock solution, high intermediates, blackened vial, and injected air)
TPB- Loss after $426 \mathrm{~h}(\%)$

82

79

23

81

No reaction $(<6 \%)$

No reaction $(<3 \%)$

\footnotetext{
* The control test repeated the protocol described in Appendix A. All tests used $2.7 \mathrm{M}$
} $\mathrm{Na}^{+}$salt solution at $25^{\circ} \mathrm{C}$ with $1 \times \mathrm{ECC}(2.6 \mathrm{mg} \mathrm{Pd} / \mathrm{L})$ unless otherwise indicated. 


\section{Effect of Platinum}

Platinum is a potential substitute for palladium based on their chemical similarity. Previous work with $\mathrm{Pd}(0)$ on titania particles showed it catalyzed the decomposition of tetraphenylborate." The effectiveness of platinum as a catalyst in simulated SRS waste was tested by substituting soluble Pt(IV) for palladium in the ECC catalyst system. However, no reaction occurred in over 800 hours at $45^{\circ} \mathrm{C}$ and the platinum concentration in solution did not decrease during the 800 hour test. The lack of reaction may indicate a slow activation step rather than lack of catalytic activity.

\section{DISCUSSION}

These test results show that the palladium catalyst can activate at $25^{\circ} \mathrm{C}$ in the absence of oxygen and that tetraphenylborate reacts at a measurable rate at $25^{\circ} \mathrm{C}$. No "temperature cliff" exists between $35^{\circ} \mathrm{C}$ and $25^{\circ} \mathrm{C}$ below which TPB' does not decompose. The rate of decomposition is first order in TPB concentration, so the rate changes as the reaction proceeds. The results of the study allow calculation of the rate of loss of TPB at $25^{\circ} \mathrm{C}$ from the rate constants and the TPB concentration. This information allows prediction of the amount of excess tetraphenylborate required to maintain low cesium concentrations in the presence of the catalytic reaction. Estimated rates of benzene generation can be calculated with additional assumptions about the stoichiometry of the reaction and the rate of decomposition of the intermediates. Future work should extract rates of decomposition of $3 \mathrm{~PB}$ and $2 \mathrm{~PB}$ from the data in the appendix of this report.

The sensitivity of the reaction to the presence of oxygen suggests the potential to prevent decomposition (or more likely, catalyst activation) by maintaining some concentration of oxygen in the slurry. The amount of oxygen required and the method of maintaining the minimum concentration require further study.

\section{UNCERTAINTIES IN CURRENT WORK}

The results of the recent tests suggest that further investigation in the following areas for would increase our understanding of the decomposition of tetraphenylborate.

- Effect of oxygen on catalyst activation and decomposition of TPB-

The results of the current tests suggest the presence of oxygen prevents catalyst activation. Additional testing to confirm this and measure the amount of oxygen required to prevent activation could lead to methods for preventing the decomposition reaction.

- Effect of Palladium concentration on reaction rate.

The lack of a rate dependence on the initial Pd concentration at $45^{\circ} \mathrm{C}$ deserves further investigation. Additional tests should monitor the change in soluble $\mathrm{Pd}$ 
and attempt to characterize the insoluble Pd produced during the reaction. This information would help understand the design requirements and process value of using palladium removal to prevent the catalyzed decomposition of tetraphenylborate.

- Reactivity of platinum.

The lack of reactivity of platinum contradicts other reports. The discrepancy may result from differences in the from of the Pt used. Resolution of this discrepancy requires additional testing. Understanding the relative reactivity of the two metals may prove necessary to interpretation of previous tests with radioactive waste. ${ }^{12}$

\section{REFERENCES}

1. M. J. Barnes, C. L. Crawford, and C. A. Nash, "Sodium Tetraphenylborate Catalyst Identification: Preliminary Studies Set 1 (U)," WSRC-TR-97-0060, Rev.0, March 6, 1997.

2. M. J. Barnes, "Sodium Tetraphenylborate Catalyst Identification: Preliminary Studies Set 2 (U)," WSRC-TR-97-0144, Rev.0, May 28, 1997.

3. M. J. Barnes and R. A. Peterson, "Sodium Tetraphenylborate Catalyst Identification: Phase A Statistical Design Studies (U)," WSRC-TR-97-0210, Rev.0, July 22, 1997.

4. M. J. Barnes and R. A. Peterson, "Sodium Tetraphenylborate Catalyst Identification: Phase B and C Statistical Design Studies (U),"WSRC-TR-97-0230, Rev.0, August 13, 1997.

5. M. J. Barnes, "Sodium Tetraphenylborate Catalyst Identification: Phase D Statistical Design Studies (U),"WSRC-TR-97-0275, Rev.0, September 5, 1997.

6. D. D. Walker, "Effect of Palladium Form on Tetraphenylborate Decomposition Rate," WSRC-TR-98-00073, Rev.0, April 13, 1998.

7. M. J. Barnes and R. A. Peterson, "Excess Sodium Tetraphenylborate and Intermediates Decomposition Studies," WSRC-TR-98-00099, Rev.0, April 7, 1998.

8. P. L. Rutland, et al, "Bases, Assumptions, and Results of the Flowsheet Calculations for the Initial Eighteen Salt Disposition Alternatives," WSRC-RP-98-00166, June 25, 1998.

9. C. L. Crawford, "Decomposition Studies of Tetraphenylborate Slurries (U)," WSRCTR-97-0046, Rev.0, May 6, 1997.

10. R. A. Peterson and T. B. Edwards, "Statistical Investigation into the Decomposition Rates of Tetraphenylborate and its Daughter Compounds (U)," WSRC-TR-97-00403, Rev.0, December, 1997. 
11. Su, Yali, to S. D. Fink, "Preliminary Studies on the Degradation of Sodium Tetraphenylborate (TPB)," unpublished results, Environmental Molecular Sciences Laboratory, Pacific Northwest National Laboratory, Richland, WA, August 5, 1997.

12. D. T. Hobbs, M. J. Barnes, R. A. Peterson, and C. L. Crawford, "Radioactive Testing Results in Support of the In-Tank Precipitation Facility," WSRC-TR-00070, Rev.0, April 2, 1998. 


\section{APPENDIX A \\ Experimental}

\section{Preparation of Slurries}

Researchers prepared simulated KTPB slurries (nominally 5 wt \% KTPB solids) with the composition shown in Table A-1. The critical feature of these slurries was the presence of excess soluble tetraphenylborate ( $\sim 15 \mathrm{mM}$ TPB $)$ but no solid NaTPB. Researchers added $\sim 0.8 \mathrm{M} \mathrm{NaTPB}$ solution to a $\sim 0.15 \mathrm{M} \mathrm{KNO}_{3}$ solution to ensure complete and rapid precipitation of KTPB, followed by addition of soluble sodium salts to achieve $2.8 \mathrm{M}$ $\mathrm{Na}^{+}$. At this point, the slurry was analyzed to verify the presence of soluble tetraphenylborate at the expected concentration based on material balance. All chemicals were reagent grade. NaTPB $(99+\%$ purity) came from Aldrich Chemical Company. Next, portions of slurry $(125 \mathrm{~mL}$ ) were placed in glass serum vials (nominal $160 \mathrm{~mL}$ internal volume). The components of the catalyst system (Table B-2) except benzene were added. Several of the tests varied particular components of the catalyst. The vials were capped and purged with nitrogen gas to remove air. In two cases, the vials were purged with air . Finally, the benzene was added via syringe and the vials shaken to mix the benzene. A $15-\mathrm{mL}$ portion of slurry was removed from each vial (initial samples). The vials were then placed in temperature controlled water baths. The vials were maintained at temperature, sealed, and unstirred for the duration of the test. The bath temperature was automatically controlled to $\pm 0.2^{\circ} \mathrm{C}$ and was checked daily with a mercury-in-glass thermometer. Periodically, the vials were removed from the baths, shaken briefly by hand, and sampled by syringe. During sampling, the vials were pressurized with nitrogen to prevent air in-leakage. The vials were out of the baths less than three minutes for each sampling.

TABLE A-1 Composition of Simulated Waste Slurry (Excluding Catalyst Components)*

\begin{tabular}{ll} 
Component & Concentration (molar) \\
\cline { 1 - 2 } $\mathrm{Na}^{+}$ & 2.8 \\
$\mathrm{NO}_{3}{ }^{-}$ & 1.07 \\
$\mathrm{NO}_{2}^{-}$ & 0.39 \\
$\mathrm{OH}^{-}$ & 0.85 \\
$\mathrm{AlO}_{2}^{-}$ & 0.17 \\
$\mathrm{CO}_{3}{ }^{2-}$ & 0.078 \\
$\mathrm{SO}_{4}{ }^{2-}$ & 0.073 \\
$\mathrm{Cl}^{-}$ & 0.013 \\
$\mathrm{~F}^{-}$ & 0.008 \\
$\mathrm{PO}_{4}{ }^{3-}$ & 0.00 \\
$\mathrm{TPB}$ & 0.0015 \\
$\mathrm{KTPB}$ & $60 \mathrm{~g} / \mathrm{L}(\sim 5 \mathrm{wt} \%)$
\end{tabular}

*See Table A-2 for catalyst components. 
TABLE A-2. Catalyst Components in Simulant Slurries

Insoluble Components (wt \% of slurry)

$1.2 \mathrm{~g} / \mathrm{L}(\sim 1 \mathrm{wt} \%)$ sludge

$1.2 \mathrm{~g} / \mathrm{L}(-1 \mathrm{wt} \%)$ monosodium titanate

Sludge composition (wt \% of dry sludge)

$\begin{array}{ll}\mathrm{Al} & 4.8 \\ \mathrm{Fe} & 18.8 \\ \mathrm{Mn} & 5.9 \\ \mathrm{Ru} & 0.23 \\ \mathrm{Rh} & 0.06 \\ \mathrm{Cr} & 0.2\end{array}$

Metal Additives (mg/L)

$\mathrm{Ca}$ (II) $\quad 12.2$

Sr(II) $\quad 0.1$

$\mathrm{La}(\mathrm{III}) \quad 0.05$

Ce(IV) $\quad 0.3$

$\mathrm{Cu}(\mathrm{II}) \quad 1.7$

$\mathrm{Ag}(\mathrm{I}) \quad 0.6$

$\mathrm{Zn}(\mathrm{II}) \quad 8.8$

Organic Additives (mg/L)

3PB

2PB

Phenol

Benzene

$\begin{array}{ll}\mathrm{Ru}(\mathrm{III}) & 0.8 \\ \mathrm{Co}(\mathrm{II}) & 0.04 \\ \mathrm{Rh}(\mathrm{III}) & 0.2 \\ \mathrm{Sn}(\mathrm{III}) & 2.1 \\ \mathrm{~Pb}(\mathrm{II}) & 1.2 \\ \mathrm{As}(\mathrm{IV}) & 0.04 \\ \mathrm{Se}(\mathrm{VI}) & 1\end{array}$

$\begin{array}{ll}\mathrm{Cu} & 0.1 \\ \mathrm{Mg} & 0.1 \\ \mathrm{Ni} & 2.5 \\ \mathrm{~Pb} & 0.3 \\ \mathrm{Zn} & 0.2 \\ \mathrm{Zr} & 2.5\end{array}$

$\mathrm{Cd}(\mathrm{II}) \quad 0.4$

$\mathrm{Hg}(\mathrm{II}) \quad 2.2$

Si(IV) 16

$\mathrm{Cr}(\mathrm{VI}) \quad 60$

Mo(VI) 12.

Fe(III) $\quad 2.6$

Diphenylmercury

Methanol

Isopropanol
150

40

\section{Analytical Results}

The samples were analyzed for organic compounds (NaTPB, 3PB, 2PB, 1PB, and phenol) and potassium ion (following loss of all soluble NaTPB). Table A-3 lists the analytical results from the initial tests and Table A-4 lists results from the followup tests.

\section{Analytical Methods}

Analytical Development Section of SRTC performed the following analyses .

Phenylboronic acid (IPB) and phenol measurements used high performance liquid chromatography (HPLC) on a Hewlett Packard LC with a $2.1 \times 250 \mathrm{~mm}$ Dychrom Chemosorb 5-ODS-UH column using acetonitrile-water eluent. Tetraphenylborate, triphenylboron (3PB), and diphenylborinic acid (2PB) measurements used the same model instrument and column with a $0.1 \%$ ammonium phosphate buffered acetonitrilemethanol-water eluent (La-mar-ka, Inc., Baton Rouge, LA). The HPLC instrument methods are described in Manual L16.1, Procedure \#ADS-2655. The methodology of sample preparation, standards, and standard preparation for HPLC analyses is described = 
consistent performance of the HPLC method. The control samples contained NaTPB, 1PB and phenol. The results for the controls agreed consistently within $\pm 10 \%$ of the average.

Potassium ion concentrations of aqueous samples used flame atomic absorption with a Varian SpectrAA-400 spectrometer. The samples were first digested in nitric acid by microwave heating. Each digested sample was diluted 1:4(sample:suppressant) in a suppressant solution of $2000 \mu \mathrm{g} / \mathrm{mL}$ cesium. For more concentrated samples, additional dilutions were made with $1600 \mu \mathrm{g} / \mathrm{mL}$ cesium. The method is described in Manual L16.1, Procedure \#ADS-1549.

Soluble palladium and platinum concentrations were measured by Inductively Coupled Plasma Mass Spectroscopy (ICP-MS) using a VG Elemental PQ2 instrument. Samples were diluted and acidified to a $\mathrm{pH}<2$ using dilute nitric acid. The method is described in Manual L16.1, Procedure \#ADS-1553. 
TABLE A-3. Analytical Results for Low Temperature Tests

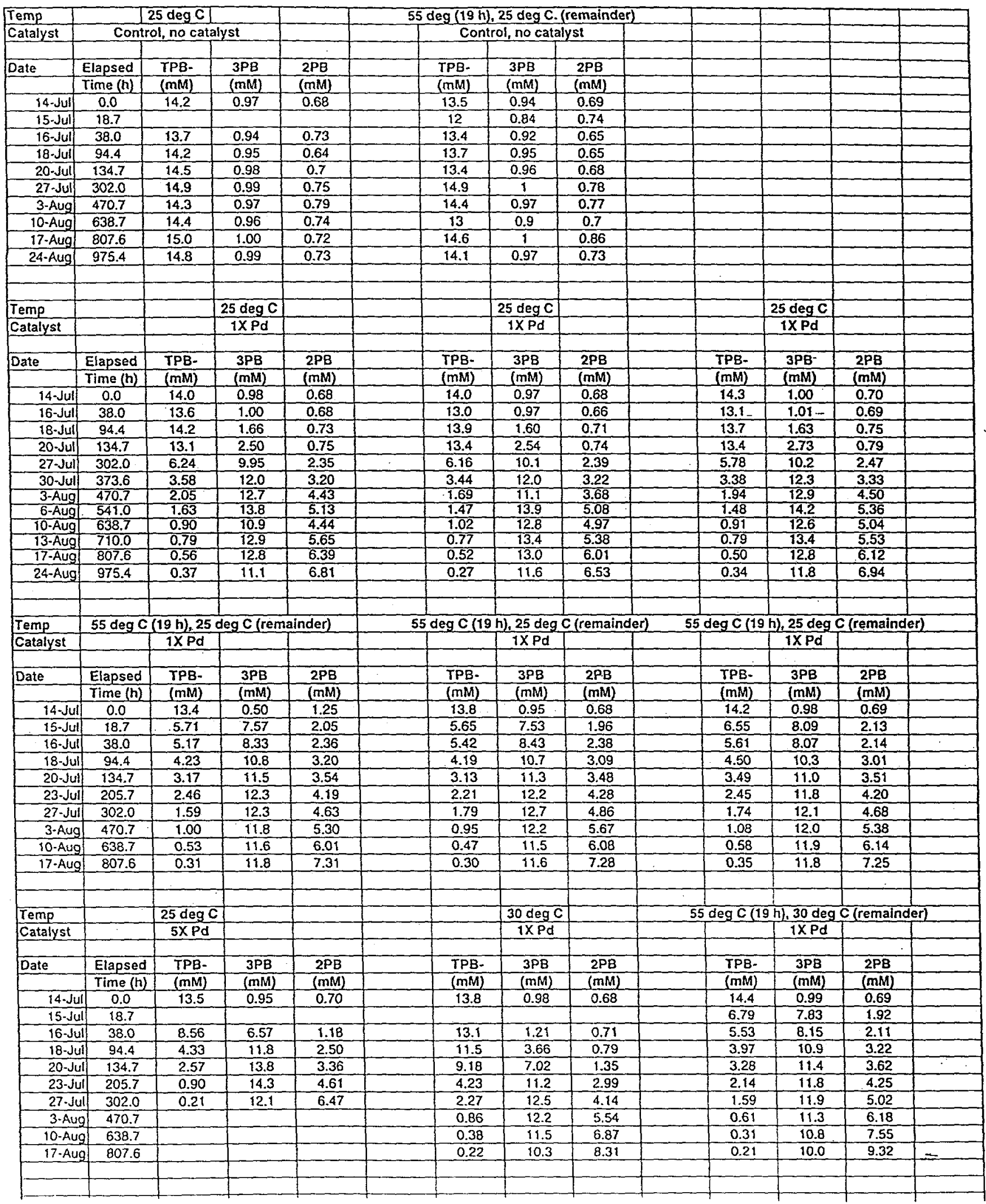


TABLE A-3. Analytical Results for Low Temperature Tests (continued)

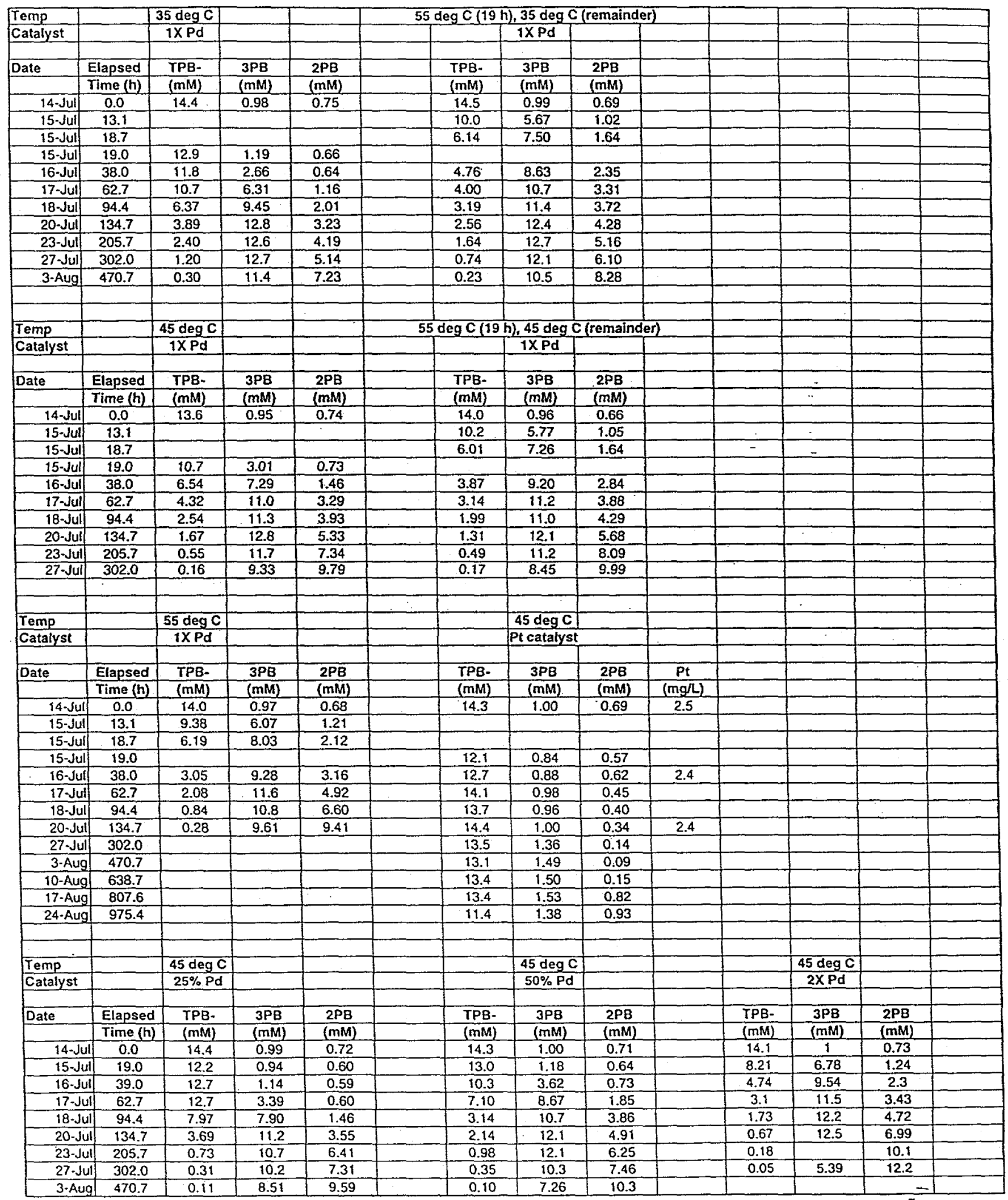


WSRC-TR-98-00342 Rev.0

Page 20 of 21

TABLE A-4. Analytical Results from Followup Low Temperature Tests

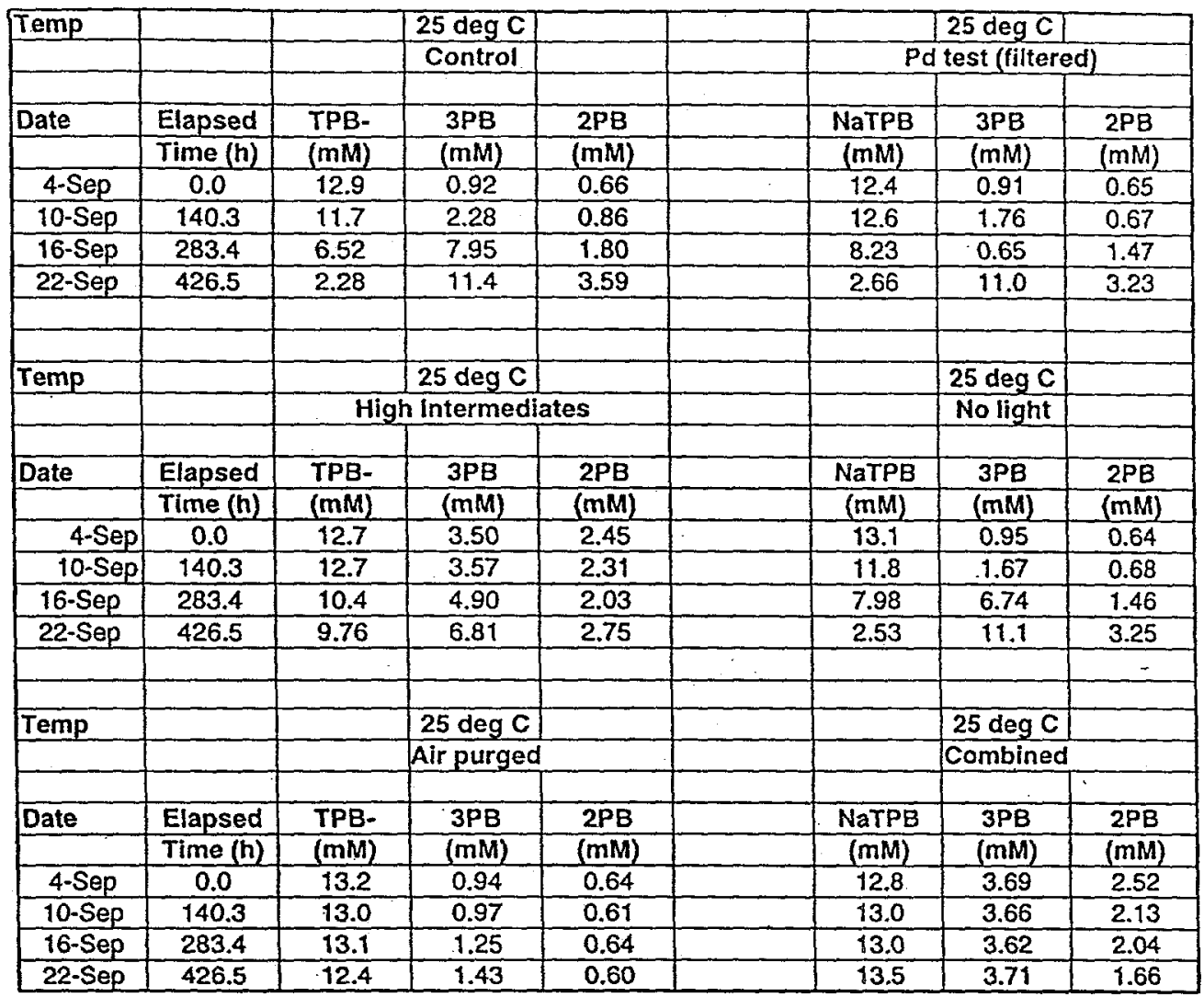


CC: G. E. Abell; 704-3N

B. N. Attaway, 773-A

J. L. Barnes, 704-3N

M. J. Barnes, 773-A

S. B. Beck, 704-3N

N. E. Bibler, 773-A

J. D. Carlson, 703-H

J. T. Carter, 704-25S

G. L. Cauthen, 241-119H

W. C. Clark, 704-56H

C. L. Crawford, 773-41 A

Dr. E. Cussler, 704-3N

N. R. Davis, 703-H

R. A. Dimenna, 773-42A

L. O. Dworjanyn, 779-2A

R. E. Eibling, 704-T

H. H. Elder, 704-S

S. D. Fink, 773-A

F. Fondeur, 773-62A

J. R. Fowler, 704-3N

M. W. Geeting, 773-24A

J. C. Griffin, 773-A

T. Hang, 773-42A

D. T. Hobbs, 773-A

E. W. Holtzscheiter, 773-A

P. I. Hudson, 704-3N

R. A. Jacobs, 704-3N

M. D. Johnson, 703-H

M. T. Keefer, 241-153H

P. S. Kirkland, 703-46A

E. J. Kosiancic, 704-3N

L. F. Landon, 704-T

B. L. Lewis, 703-H
T. J. Lex, 703-H

P. E. Lowe, 773-41 A

D. J. McCabe, 773-42A

J. W. McCollough, 703-H

M. S. Miller, 704-56H

T. M. Monahon, 703-H

J. P. Morin, 703-H

E. T. Murphy, 704-3N

C. A. Nash, 773-42A

L. M. Nelson, 773-43A

L. M. Papouchado, 773-A

P. K. Paul, 773-42A

R. A. Peterson, 773-A

S. F. Piccolo, 704-3N

M. R. Poirier, 676-T

M. J. Polochko, 773-A

K. J. Rueter, 706-S

P. L. Rutland, $704-196 \mathrm{~N}$

R. H. Spires, 703-H

W. E. Stevens, 773-A

P. C. Suggs, 704-3N

R. F. Swingle, 773-A

W. L. Tamosaitis, 773-A

G. A. Taylor, $704-196 \mathrm{~N}$

W. B. VanPelt, 676-1T

D. D. Walker, 773-A

Dr. J. Watson, 704-3N

W. R. Wilmarth, 773-42A

G. T. Wright, 773-A

J. E. Young, 773-A

TIM, 703-43A

WPTS Files, 773-A, c/o S. Poston, 773-A

ITP files, c/o A. G. Wiest, 241-119H 